\title{
Salubrity and salvation
}

\author{
Giorgio Bordin
}

Received: 15 October 2010/ Accepted: 18 October 2010/Published online: 3 November 2010

(C) Springer-Verlag 2010

We stated in the last issue that "already in the very substance of suffering lies a hope for salvation-or salubritysince both words stem from their common Latin root: salus" [1]. This awareness grew at the very beginning of Christian culture.

Jesus of Nazareth became very famous in the countries neighbouring Palestine, mostly as a healer. Even in the Parthenon, in Rome, there will be a place for a portrait of Him.

Jesus healed many sick men through miracles which were made as signs of something else: eternal happiness, which started already in the present day. His healing of the body, however, did not lessen the great query for salvation which underlies the need for salubrity, rather it deepened that very call for salvation which the disease itself aroused.

In our professional experience we can also witness that even clinical success is in its nature transitory and fails to fully satisfy the demand of the human heart: healing the body is not enough.

An episode, here shown through the depiction in the mosaics at the Cathedral of Monreale and taken from the Gospel of Luke, helps us to understand this point.

The story goes as follows. Ten lepers met Jesus and asked his pity; "And when he saw them, he said unto them, 'Go, show yourselves unto the priests.' And it came to pass, that, as they went, they were cleansed". One of them came back ("and he was a Samaritan") to Christ "and with a loud voice glorified God (...) And Jesus answering said,

G. Bordin $(\square)$

Ospedale Piccole Figlie, Parma, Italy

e-mail: giorgio.bordin@fastwebnet.it

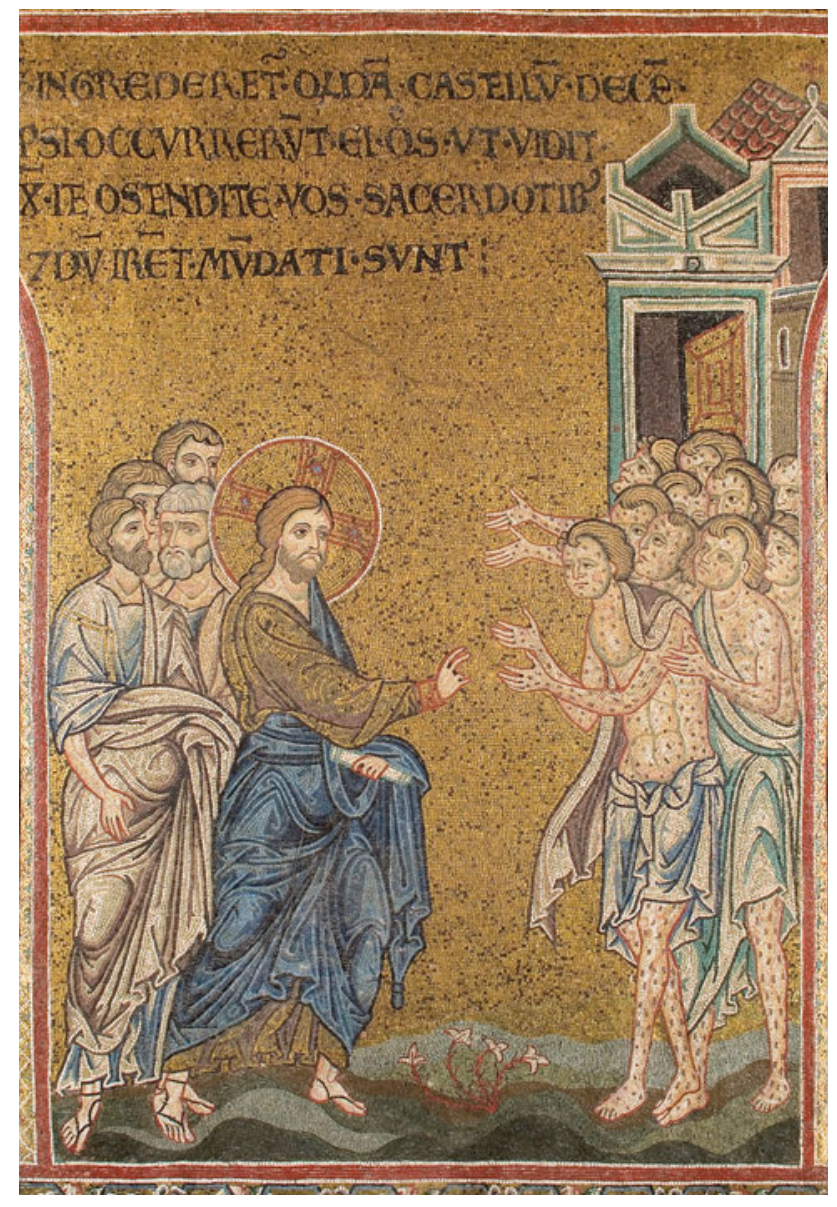

Fig. 1 Allegory of the ten lepers. Mosaic, anonymous. Cathedral of Monreale (XII century, Sicily, Italy), lateral northern aisle 
'Were there not ten cleansed? Where are the nine? There are not found that returned to give glory to God, save this stranger?' And he said unto him, 'Arise, go thy way; thy faith hath made thee whole.,"

The beggarly hands of the lepers are depicted before the benedictory hands of Christ. The disciples can be seen looking on, stunned by the power of this man. But an even greater revelation is still to come: the fact that even within a disease a man can discover the meaning of his whole life. It is to allow this knowledge-which is totally dependent upon the freedom of the individual-that the cure of the sick emerges in the culture to which we belong (Fig. 1).

\section{Reference}

1. Bordin G (2010) Ecce Homo. The man of suffering, the suffering of man. J Med Pers 8(2):88-89 